\title{
TSUNAMI RISK ASSESSMENT MODELLING IN CHABAHAR PORT, IRAN
}

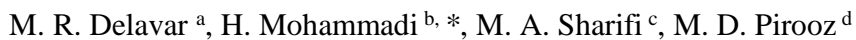 \\ ${ }^{a}$ Centre of Excellence in Geomatics Eng. in Disaster Management, School of Surveying and Geospatial Eng, College of Eng, University of Tehran, \\ Tehran, Iran, mdelavar@ut.ac.ir \\ ${ }^{\mathrm{b}}$ GIS Dept., School of Surveying and Geospatial Eng. College of Eng., University of Tehran, Tehran, Iran, ho.mohammadi@ut.ac.ir \\ c Geo-Information Science and Earth Observation, University of Twente, Enschede, The Netherlands, alisharifi@itc.nl \\ ${ }^{\mathrm{d}}$ School of Civil Eng., College of Eng., University of Tehran, Tehran, Iran, mdolat@ ut.ac.ir
}

Commission IV, WG IV/3

KEY WORDS: Tsunami Risk Assessment, Makran Subduction Zone (MSZ), Tsunami Generation, Propagation, and Inundation

\begin{abstract}
:
The well-known historical tsunami in the Makran Subduction Zone (MSZ) region was generated by the earthquake of November 28, 1945 in Makran Coast in the North of Oman Sea. This destructive tsunami killed over 4,000 people in Southern Pakistan and India, caused great loss of life and devastation along the coasts of Western India, Iran and Oman. According to the report of "Remembering the 1945 Makran Tsunami", compiled by the Intergovernmental Oceanographic Commission (UNESCO/IOC), the maximum inundation of Chabahar port was $367 \mathrm{~m}$ toward the dry land, which had a height of 3.6 meters from the sea level. In addition, the maximum amount of inundation at Pasni (Pakistan) reached to $3 \mathrm{~km}$ from the coastline. For the two beaches of Gujarat (India) and Oman the maximum run-up height was $3 \mathrm{~m}$ from the sea level. In this paper, we first use Makran 1945 seismic parameters to simulate the tsunami in generation, propagation and inundation phases. The effect of tsunami on Chabahar port is simulated using the ComMIT model which is based on the Method of Splitting Tsunami (MOST). In this process the results are compared with the documented eyewitnesses and some reports from researchers for calibration and validation of the result. Next we have used the model to perform risk assessment for Chabahar port in the south of Iran with the worst case scenario of the tsunami. The simulated results showed that the tsunami waves will reach Chabahar coastline 11 minutes after generation and 9 minutes later, over $9.4 \mathrm{Km}^{2}$ of the dry land will be flooded with maximum wave amplitude reaching up to 30 meters.
\end{abstract}

\section{INTRODUCTION}

The 2004 Indian Ocean tsunami was the worst tsunami disaster in history. The tsunami caused by the giant Sumatra-Andaman earthquake (Mw 9.3) on December 26, 2004, devastated the shores of the Indian Ocean. The total number of victims dead and missing together, was estimated as 230,000 , the largest in Indonesia (163.795), followed by Sri Lanka $(35,399)$, India (16,389), Thailand (8,345), and Somalia (298) (Kenji and Yushiro., 2007). Makran Subduction Zone (MSZ) located in the north-west of the Indian Ocean is among the most tsunami genic sources in this ocean. The Makran zone results from the convergence between the Arabian plates with the Eurasian plate at an estimated rate of about $19 \mathrm{~mm} /$ year Figure 1, (Heydarzadeh et al., 2008). This zone extends east from the Strait of Hormoz in Iran to near Karachi in Pakistan with a length of about $900 \mathrm{Km}$. Historically, there is a potential for tsunami generation in this region and several tsunamis attacked the Makran coastline in the past such as 326 BC, 1008, 1897 and 1945. The 1945 tsunami was one of the most deadly tsunamis ever in the Makran region which occurred on 28 November 1945 off the southern coast of Iran and Pakistan. This event was the deadliest tsunami after 2004 Sumatra, which took the lives of more than 4000 people on the Makran coast (Heydarzadeh et al., 2008). According to the report of "Remembering the 1945 Makran Tsunami", provided by Intergovernmental Oceanographic Commission (UNESCO/IOC) with survivors beside the Oman Sea, the maximum inundation tsunami for Chabahar port was $367 \mathrm{~m}$ toward the dry land, where height from the sea level was 3.6 meters. While the amount of maximum tsunami inundation at Pasni (Pakistan) reached to $3 \mathrm{Km}$ from the coastline to the dry land, for both beaches of Gujarat (India) and Oman, the maximum run-up height was $3 \mathrm{~m}$ from the sea level. To simulate the tsunami generation, propagation and inundation phases, we used the Community Interface Tsunami Model (ComMIT) (nctr.pmel.noaa.gov/ComMIT/). The ComMIT model was initially developed for Indian Ocean countries after the 2004 Indian Ocean tsunami, which supported and developed by the United Nations Educational, Scientific, and Cultural Organization (UNESCO), the United States Agency for International Development (USAID), and the National Oceanic and Atmospheric Administration (NOAA). The ComMIT model is based on the Method of Splitting Tsunami (MOST) (Titov and Synolakis., 1995, 1997). In this research we used ComMIT model as one of the two validated hydrodynamic models for operational tsunami propagation and inundation (Titov and Gonzalez, 1997). MOST uses the final dislocation field from the seismic deformation model to initialize hydrodynamic computations. MOST takes into account on land crustal deformation from the earthquake and computes the wave evolution and run-up onto dry land over the newly deformed bathymetry and topography. In this research we have first simulated Makran 1945 tsunami and its effects on the Chabahar port, Iran through comparison of the results with data collected and presented in various reports. After validation of the model, it was used to simulate the impact of the worst-case scenario to Chabahar port. This paper presents the basic principles of Makran 1945 tsunami simulation model for generation, propagation and inundation phases for Chabahar port. In this process the 
simulation results have been compared with documented eyewitnesses as well as reports from researchers regarding 1945 Makran tsunami. The simulation results of the worst case scenario for Chabahar port against tsunami are presented.

\section{SIMULATION OF MAKRAN 1945 TSUNAMI}

The devastating earthquake had been occurred at 21:56 UTC (03:26 IST), on 28 November 1945 in Makran Subduction Zone. Its epicentre was off the Makran coast at 24.2 N, 62.6 E according to USGS, in the north of Oman Sea, about $100 \mathrm{Km}$ south of Karachi and about $87 \mathrm{Km} \mathrm{SW}$ of Churi (Baluchistan) Pakistan. The quake's focal depth was $27 \mathrm{Km}$. The earthquake's Richter Magnitude (Ms) was 7.8. The Moment Magnitude (Mw) was later given as 7.9 and re-evaluated to be 8.1 (Pacheco and Sykes, 1992). The quake was recorded by observatories in New Delhi, Kolkata (Calcutta) and Kodaikanal. Its intensity was high throughout the region. It was strongly felt in Baluchistan and the Las Bela area of Pakistan. It was reported that in the western and southern sections of Karachi, the strong surface motions lasted for about 30 Seconds. Figure 1, illustrates the location of the Makran 1945 tsunami and the other earthquakes greater than 7 Richter which caused tsunami to MSZ region.

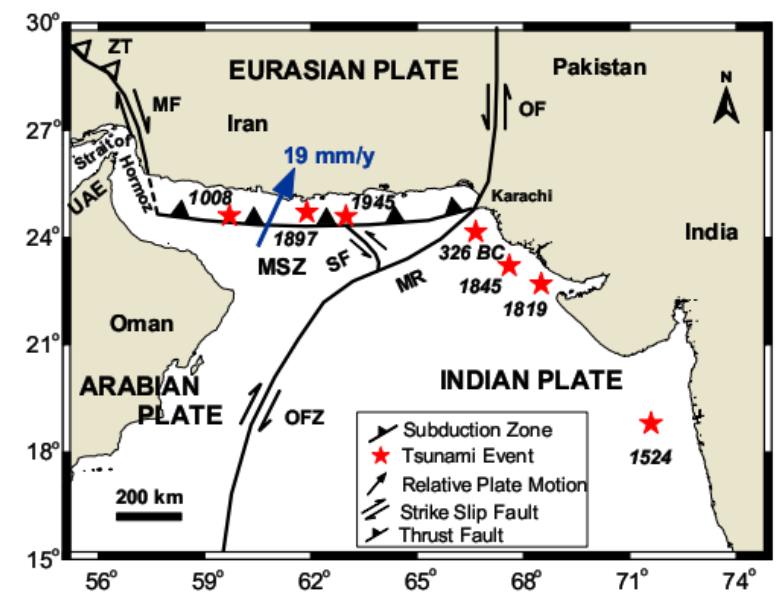

Figure 1. The tectonic map of the Makran subduction zone and historical tsunamis. Abbreviation are: Makran Subduction Zone (MSZ), Zagros thrust (ZT), Minab Fault (MF), Senne Fault (SF), Murray Ridge (MR), Owen Fracture Zone (OFZ), and Ornach-Nal Fault (OF). (Heidarzadeh et al., 2007).

The tsunami modelling process can be divided into three phases including generation, propagation, and run-up (inundation) (Synolakis, 2003). Generation forms the first stage in the modelling of tsunami which includes the calculation of the initial disturbance of ocean surface due to the earthquake-triggered deformation of the seafloor using seismic parameters. A hydrodynamic model takes the initial wave and models tsunami waves at the propagation and run-up phases (Satake, 1995).

\subsection{Generation Phase}

The generation phase of tsunami evolution includes the formation of the initial disturbance of the ocean surface due to the earthquake-triggered deformation of the seafloor. This initial water-surface disturbance evolves into a long gravity wave radiating from the earthquake source. The ComMIT model is a full package for simulation all the three tsunami phases include generation, propagation and inundation (run-up). For handling the generation phase, the ComMIT model used equation developed based on a fault plane model of the earthquake source (Okada, 1985) which assumes an incompressible liquid layer on an underlying elastic half space to characterize the ocean and the Earth's crust. The implementation of this elastic fault plane model (Titov and Synolakis 1997) utilizes a formula for static sea-floor deformation to calculate the initial conditions required for subsequent computations of tsunami propagation and inundation phases. Tsunamis are generated by sudden vertical displacement of ocean floor due to earthquake occurrence in the location of subduction zones. The pattern and extent of vertical ground deformation from an earthquake uniquely determines whether or not a tsunami is formed (Synolakis, 2003). Hence, for tsunami modelling at first, the size and distribution of ocean floor deformation following an undersea earthquake should be calculated. To address this problem, Steketee (1958) for the first time applied Volterra's formula (Equation 1), for the general study of dislocations in an elastic half-space (Mansinha and Smylie, 1971).

$$
u_{i}=\int_{\Sigma} \Delta u_{j}\left[\delta_{j k} \lambda \frac{\partial u_{i}^{1}}{\partial \xi_{1}}+\mu\left(\frac{\partial u_{i}^{j}}{\partial \xi_{k}}+\frac{\partial u_{i}^{k}}{\partial \xi_{i}}\right)\right] v_{k} d S
$$

Where the integral is over the dislocation surface, $v_{k}$ is the outward normal vector to $\sum, \mu$ and $\lambda$ are the Lame constants, and $u_{i}^{j}$ is the ith component of displacement at $\left(\mathrm{X}_{1}, \mathrm{X}_{2}, \mathrm{X}_{3}\right)$ due to a point force of unit magnitude at $\left(\xi_{1}, \xi_{2}, \xi_{3}\right)$ acting in the $\mathrm{j}$ direction. Volterra's formula gives the displacement field as an integral over the fault surface involving nuclei of strain which can be interpreted as being due to the action of systems of point forces (Mansinha and Smylie, 1971). Since dislocation theory was first introduced to the field of seismology by Steketee (1958), numerous theoretical formulations describing the deformation of an isotropic homogeneous semi-infinite medium have been developed with increasing completeness and generality of source type and geometry (Okada, 1985). Okada (1985) using Volterra's formula developed integral equations for displacement fields of rectangular slip faults. Then, he analytically solved the extracted integral equations and proposed closed analytical expressions for the displacement fields of inclined, finite strike-slip and dip-slip faults Figure 2 and Figure 3.

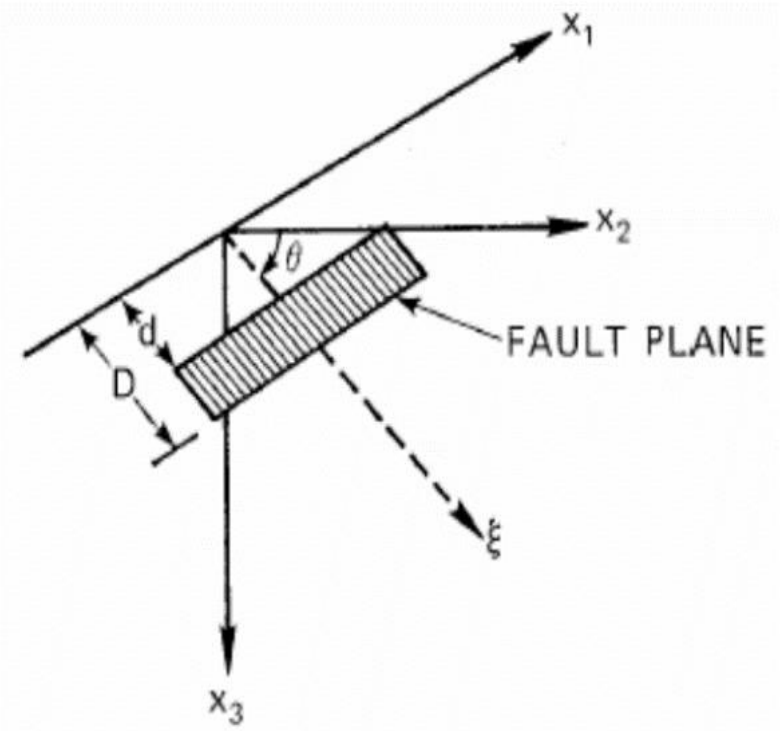

Figure 2. Fault geometry and coordinate axis (Heidarzadeh et al., 2007). 


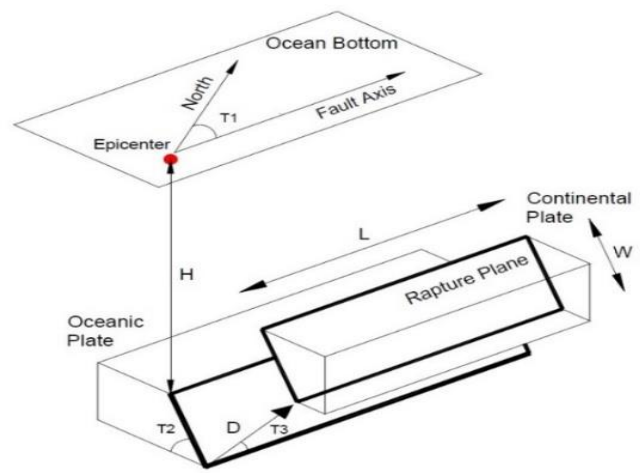

Figure 3. Parameters used for tsunami source modelling including length of rupture (L), width of rupture (W), depth of epicentre from sea floor surface (H), slip (D), dip (T3), strike (T1) and slip/rake (T2) (Heidarzadeh et al., 2007).
Here, the algorithm of Okada (1985) was used to calculate the seafloor deformation due to the earthquake. This algorithm calculates the ground deformation using input seismic parameters including the strike, dip, and slip angles, the amount of slip, the dimensions (length and width) of the rupture area, and the earthquake depth (Synolakis, 2003). The seismic parameters are estimated in the study by Byrne et al. (1992) and calibrated by Heidarzadeh et al. (2008) used for tsunami generation modelling presented in Table 1.

A critical part of any scientific modelling effort is model calibration and validation in which comparisons between model predictions and actual field data are accomplished. In this study, for calibration and validation of the model, we employed the model to calculate seafloor uplift of some actual tsunami events and compared the results obtained from the model with actual field data. The maximum calculated uplift using these seismic parameters was about $2 \mathrm{~m}(1.84 \mathrm{~m})$ which was in agreement with the actual observed uplift during the 1945 event Figure 4.

\begin{tabular}{|c|c|c|c|c|c|c|c|c|c|}
\hline Name of event & $\begin{array}{c}\text { Dip } \\
\left({ }^{\circ}\right)\end{array}$ & $\begin{array}{c}\text { Slip } \\
\left({ }^{\circ}\right)\end{array}$ & $\begin{array}{c}\text { Strike } \\
\left({ }^{\circ}\right)\end{array}$ & $\begin{array}{c}\text { Depth } \\
(\mathrm{Km})\end{array}$ & $\begin{array}{c}\text { Length } \\
(\mathrm{Km})\end{array}$ & $\begin{array}{c}\text { Width } \\
(\mathrm{Km})\end{array}$ & $\begin{array}{c}\text { Slip } \\
(\mathrm{m})\end{array}$ & $\begin{array}{c}\text { Moment } \\
(\mathrm{N} \mathrm{m})^{\mathrm{a}}\end{array}$ & $\begin{array}{c}\text { Uplift } \\
(\mathrm{m})\end{array}$ \\
\hline $\begin{array}{c}\text { 1945 Makran earthquake } \\
\left(\mathrm{M}_{\mathrm{w}} 8.1\right)\end{array}$ & 7 & 89 & 246 & 27 & 130 & 70 & 6.6 & $1.8 \times 10^{21}$ & 2 \\
\hline
\end{tabular}

Table 1. Seismic parameters of the Makran 1945 tsunami (Heidarzadeh et al., 2008)

${ }^{\text {a }}$ The rigidity of the earth is about: $3.0 \times 1010 \mathrm{~N} / \mathrm{m}^{2}$ in the Makran region

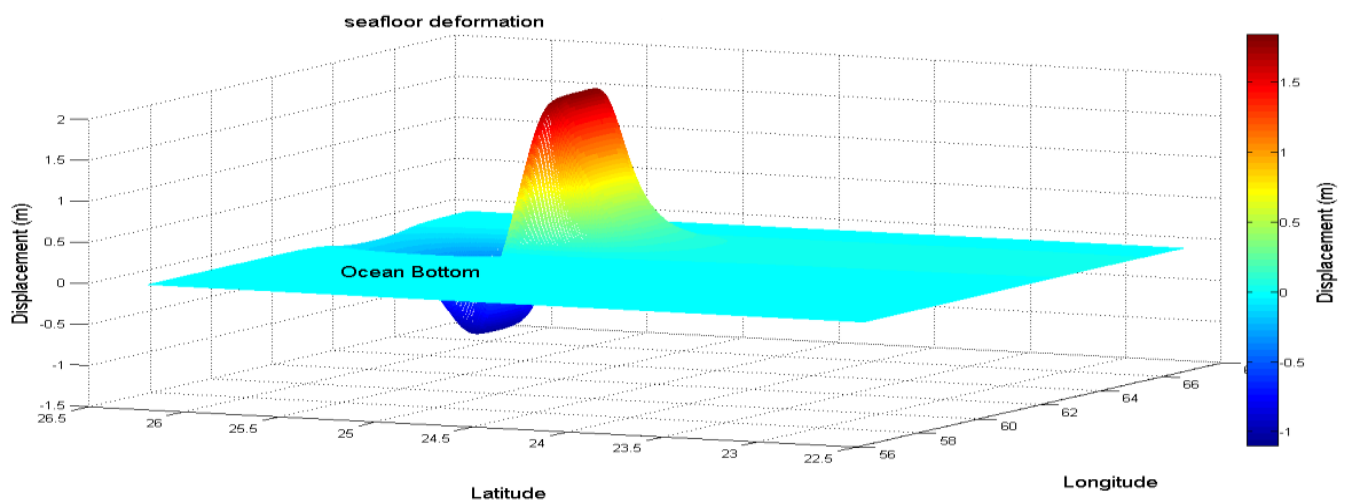

Figure 4. Simulation of three-dimensional sea floor deformation in the earthquake of 1945 MSZ. The amount of maximum uplift is $1.839 \mathrm{~m}$. and max subsidence is $1.099 \mathrm{~m}$.

\subsection{Propagation and Run-up Modelling and Validation}

A tsunami can propagate long distances before it strikes a shoreline hundreds or thousands of kilometres from the earthquake source. To accurately model tsunami propagation over such large distances, the Earth's curvature should be taken into account. Other factors such as Coriolis forces ${ }^{1}$ and dispersion, may also be important. The ComMIT model use three nested different resolution Geospatial data for tsunami simulation. The MOST propagation model uses a numerical dispersion scheme and the non-linear shallow-water wave equations in spherical coordinates, with Coriolis terms (Murty, 1984):

$$
h_{t}+\frac{(u h)_{\lambda}+(v h \cos \phi)_{\phi}}{R \cos \phi}=0
$$

$$
\begin{gathered}
u_{t}+\frac{u u_{\lambda}}{R \cos \phi}+\frac{v u_{\phi}}{R}+\frac{g h_{\lambda}}{R \cos \phi}=\frac{g d_{\lambda}}{R \cos \phi}+f v \\
v_{t}+\frac{u v_{\lambda}}{R \cos \phi}+\frac{v v_{\phi}}{R}+\frac{g h_{\phi}}{R}=\frac{g d_{\phi}}{R}-f u,
\end{gathered}
$$

where $\lambda$ is Longitude, $\phi$ is Latitude, $h=h(\lambda, \phi, t)+d(\lambda, \phi, t)$, $h(\lambda, \phi, t)$ is the amplitude, $d(\lambda, \phi, t)$ is the undisturbed water depth, $u(\lambda, \phi, t)$ and $v(\lambda, \phi, t)$ are the depth-averaged velocities in the Longitude and Latitude directions, respectively, $g$ is the gravity acceleration, $f$ is the Coriolis parameter $(f=2 \omega \sin \phi)$, and $\mathrm{R}$ is the earth radius. In the MOST model, these equations are solved numerically using a splitting method similar to that described by Titov and Synolakis (1997). For propagation and

\footnotetext{
${ }^{1}$ The Coriolis force applies to movement on rotating earth
} 
run-up modelling, three nested layer girds with different resolutions have been used. The exterior layer grid with 30 arc seconds $\sim 980$ meters, layer grid $\mathrm{A}$, is with dimensional domain of $1267 \times 665$ consisting of 842555 points, whereas for middle layer, grid B, with 180 meters resolution and $745 \times 385$ dimension domain consisting 286825 points and then for layers grid $\mathrm{C}$ with spatial dimension of $1085 \times 453$ consisting 941505 points with 15 meters resolution were considered as shown in Table 2, And Figure 5. Table 2 shows the topographic and bathymetric data parameters employed for the tsunami simulation. Figure 6(a) illustrates the tsunami wave at generation time on exterior layer A. Figure 6(b) illustrates the tsunami wave at generation time on grid layer C. Figure 6(c) illustrates the tsunami wave at 35 minutes after generation on grid layers A. Figure 6(d) illustrates the tsunami wave at 35 minute afters generation time. Figure 7 , illustrates the maximum wave amplitude recorded tsunami waves during a two-hour simulation. The Makran earthquake and tsunami of 1945, which was the only instrumentally recorded tsunami in the northwest of Indian Ocean, was used for calibration and validation of our tsunami modelling process.
Some authors (e.g. Ambraseys and Melville, 1982; Page et al., 1979) reported that the ocean floor experienced about $2 \mathrm{~m}$ of uplift due to this earthquake. Ambraseys and Melville (1982) reported that the tsunami wave height was approximately $4-5 \mathrm{~m}$ in Pasni, about $1.5 \mathrm{~m}$ in Karachi, and $2 \mathrm{~m}$ in Mumbai. Also according to the collected reported from "Remembering the 1945 Makran Tsunami", the maximum run-up in Chabahar coastline was 3.6 meters. Our model successfully reproduced 2 meters uplifting at the generation phase, as mentioned in section 2.1 generation phase illustrate in at the Figure 4. For the propagation and inundation phases, the observed wave height of $3 \mathrm{~m}$ run-up and 300 meters inundation at Chabahar coastline were calculated in this research as shown in Figure 7, verified by the eyewitnesses' reports. According to the geo-spatial data used for the tsunami modeling, the seismic parameters employed and the uncertainty exists in the coastal border line, and model used, the accuracy of final rezults have been soccessfuly verified by eyewitnesses of reports.

\begin{tabular}{|c|c|c|c|c|c|c|}
\hline \multirow{2}{*}{ Type of data } & \multirow{2}{*}{$\begin{array}{l}\text { Resolution } \\
\text { (meters) }\end{array}$} & \multirow{2}{*}{$\begin{array}{l}\text { Dimensional } \\
\text { Grid domain } \\
(\mathrm{m})\end{array}$} & \multirow{2}{*}{ Resource } & \multirow{2}{*}{$\begin{array}{l}\text { Grid } \\
\text { Layers }\end{array}$} & \multicolumn{2}{|c|}{ Boundary Extension } \\
\hline & & & & & Easting & Northing \\
\hline $\begin{array}{l}\text { Bathymetric } \\
\text { and } \\
\text { Topographic }\end{array}$ & 980 & $1267 \times 665$ & $\begin{array}{l}\text { General Bathymetric Chart of } \\
\text { the Oceans (GEBCO), UK. }\end{array}$ & A & $\begin{array}{l}56^{\circ} 00^{\prime} 05.76^{\prime \prime}, \\
66^{\circ} 33^{\prime} 45.00^{\prime \prime}\end{array}$ & $\begin{array}{l}20^{\circ} 50^{\prime} 57.84^{\prime \prime}, \\
26^{\circ} 24^{\prime} 02.69^{\prime \prime}\end{array}$ \\
\hline Bathymetric & 180 & \multirow[t]{2}{*}{$745 \times 385$} & $\begin{array}{c}\text { Extracted 10-20 meters data } \\
\text { from National Cartographic } \\
\text { Centre (NCC), Iran }\end{array}$ & \multirow[t]{2}{*}{ B } & \multirow[t]{2}{*}{$\begin{array}{l}59^{\circ} 55^{\prime} 09.18^{\prime \prime}, \\
61^{\circ} 09^{\prime} 40.27^{\prime \prime}\end{array}$} & \multirow[t]{2}{*}{$\begin{array}{l}24^{\circ} 49^{\prime} 32.74^{\prime \prime}, \\
25^{\circ} 28^{\prime} 03.30^{\prime \prime}\end{array}$} \\
\hline DEM & 180 & & ASTER & & & \\
\hline Bathymetric & 15 & \multirow{2}{*}{$1085 \times 453$} & National Cartographic Centre & \multirow{2}{*}{$\mathrm{C}$} & \multirow{2}{*}{$\begin{array}{l}60^{\circ} 35^{\prime} 32.39^{\prime \prime}, \\
60^{\circ} 44^{\prime} 58.54^{\prime \prime}\end{array}$} & \multirow{2}{*}{$\begin{array}{l}25^{\circ} 15^{\prime} 15.81^{\prime \prime}, \\
25^{\circ} 19^{\prime} 12.18^{\prime \prime}\end{array}$} \\
\hline DEM & 15 & & & & & \\
\hline
\end{tabular}

Table 2. Geo-spatial data used for Tsunami Simulation

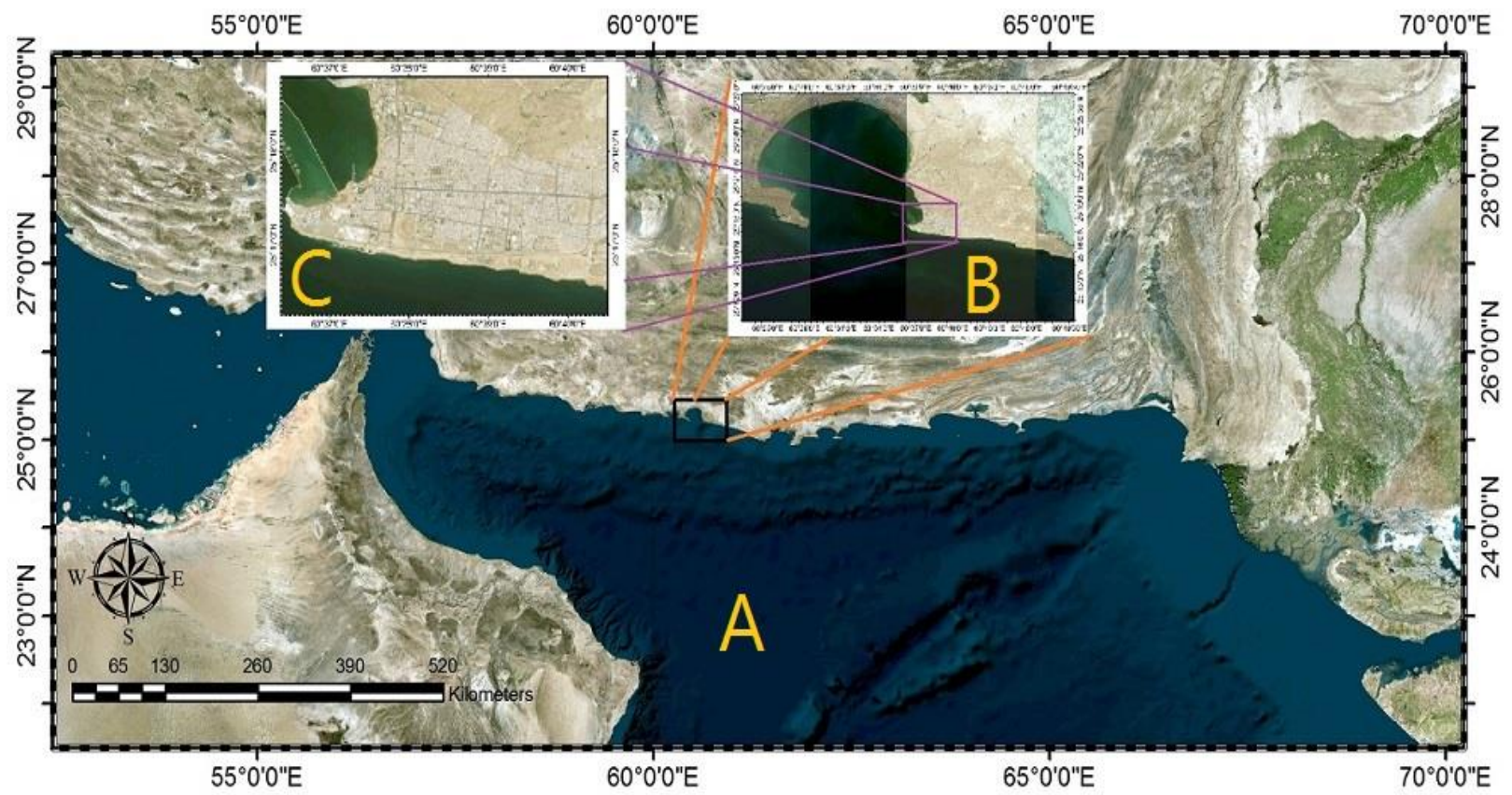

Figure 5. The study area used for Tsunami Simulation. The first layer is 980 meters resolution (A), the middle layer is 180 meters resolution (B) and the top layer Chabahar Port with 15 meters resolution(C). 

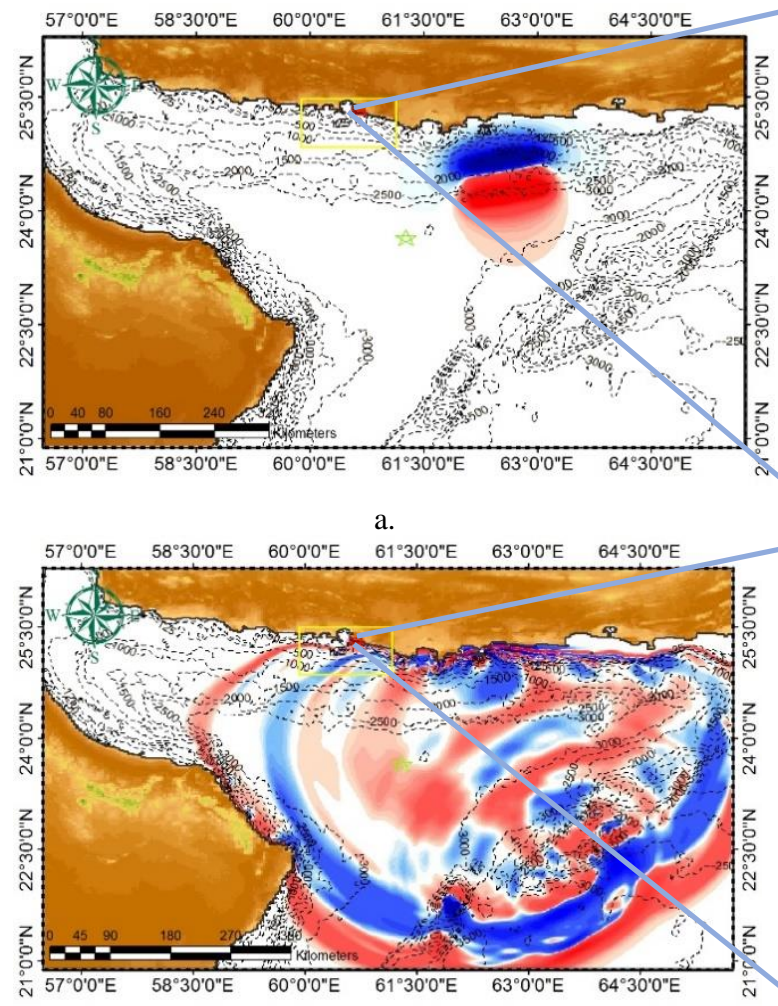

c.

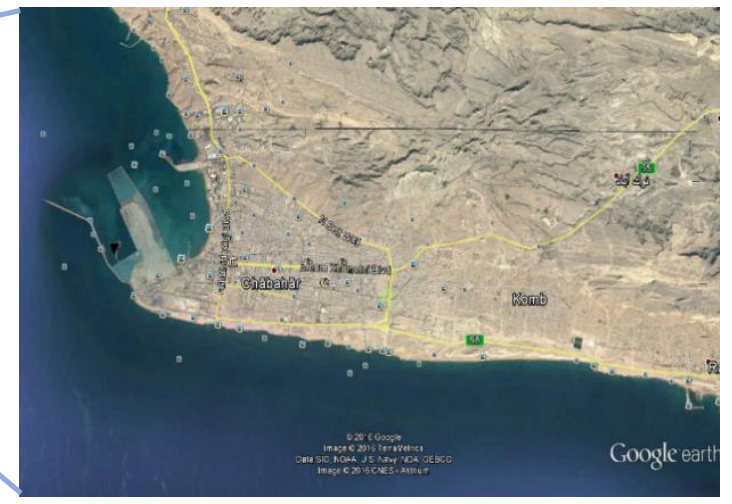

b.

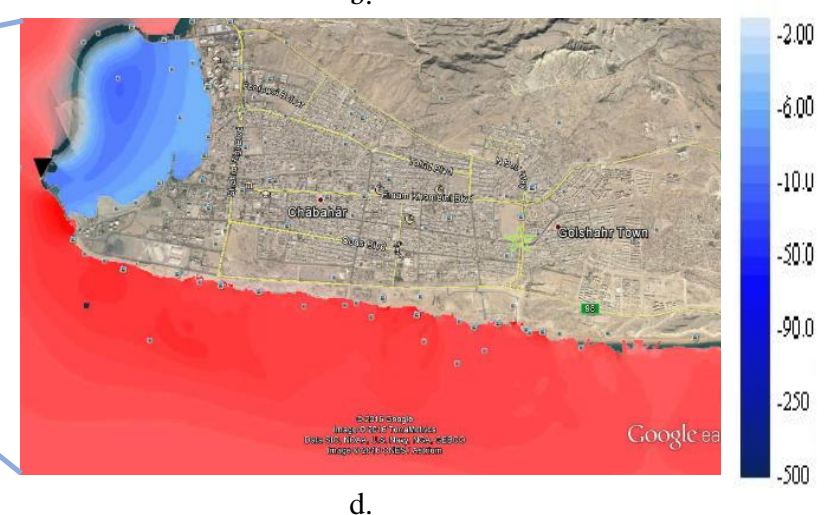

d.

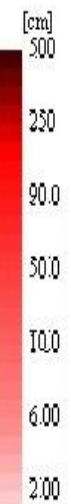

200

2.00

0

0

50

00

Figure 6. Snapshot of sea level deformation in the Makran subduction zone affected tsunami, at the generation time on grid layer A (a), Chabahar port at the tsunami generation time on grid layer $\mathrm{C}$ (b), propagation of the tsunami waves at 35 minutes after the generation on grid layer A (c), inundation tsunami at 35 minutes after the generation on grid layer $\mathrm{C}$ (d).

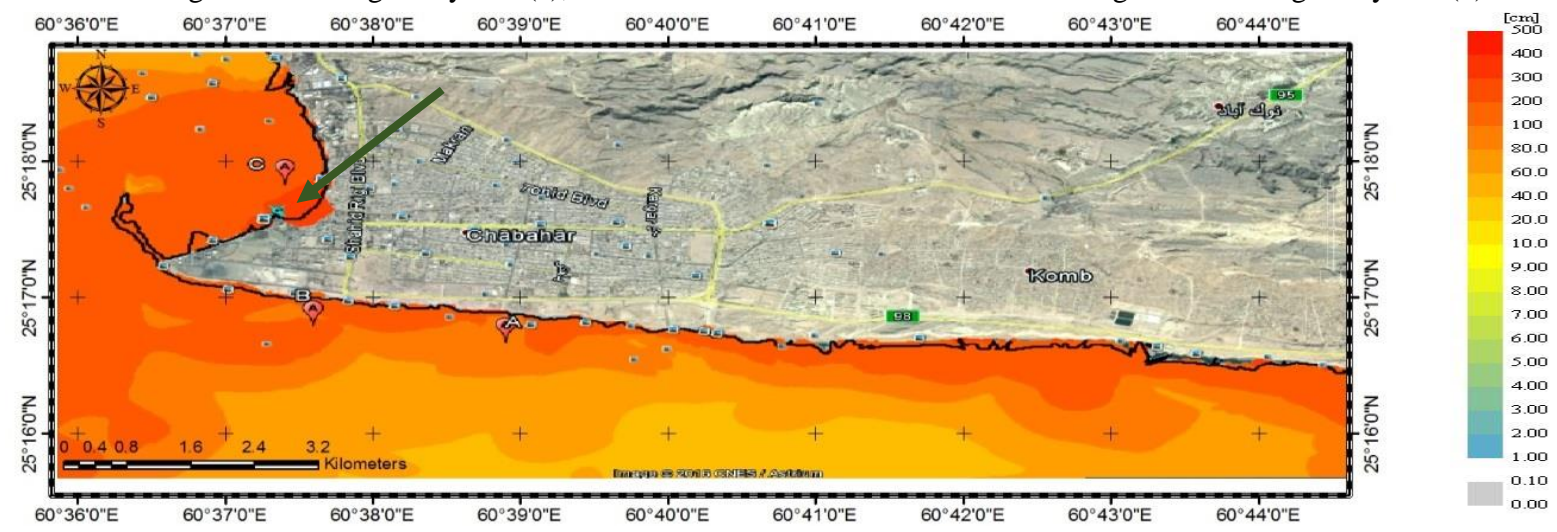

Figure 7. Maximum waves amplitude recorded during a two-hour simulation in the Chabahar port. The maximum wave amplitude is 3 meters (assigned by arrow), and the maximum inundation area is $1.2 \mathrm{Km}^{2}$

\section{THE WORST CASE TSUNAMI SCENARIO FOR CHABAHAR PORT}

After verification of the modelling results, we simulated the worst case scenario for Chabahar port as suggested by Hydarzadeh et al. (2008) to perform tsunami risk assessment for the port. Therefore, we used seismic parameters presented in Table 3, for the worst case scenario simulation. In this process, we have also used the topographic and bathymetric data presented in Table 2. According to Figure 8, the simulation results illustrated that, the tsunami waves will reach Chabahar coastline, 11 minutes after generation, and 9 minutes later $(20$ minutes after generation) over $9.4 \mathrm{Km}^{2}$ of dry land will be flooded with maximum wave amplitude reaching up to 30 meters.

\begin{tabular}{|c|c|c|c|c|c|c|c|}
\hline $\operatorname{Dip}\left({ }^{\circ}\right)$ & Slip $\left(^{\circ}\right)$ & Strike $\left(^{\circ}\right)$ & Depth $(\mathrm{Km})$ & Length $(\mathrm{Km})$ & Width $(\mathrm{Km})$ & $\operatorname{Slip}(\mathrm{m})$ & $\operatorname{Moment}(\mathrm{N} \mathrm{m})^{\mathrm{a}}$ \\
\hline 10 & 90 & 270 & 30 & 130 & 70 & 15 & $1.8 \times 10^{21}$ \\
\hline
\end{tabular}

Table 3. Seismic parameters of the Makran tsunami of the worst case tsunami scenario 
a The rigidity of the earth is about: $3.0 \times 1010 \mathrm{~N} / \mathrm{m} 2$ in the Makran region

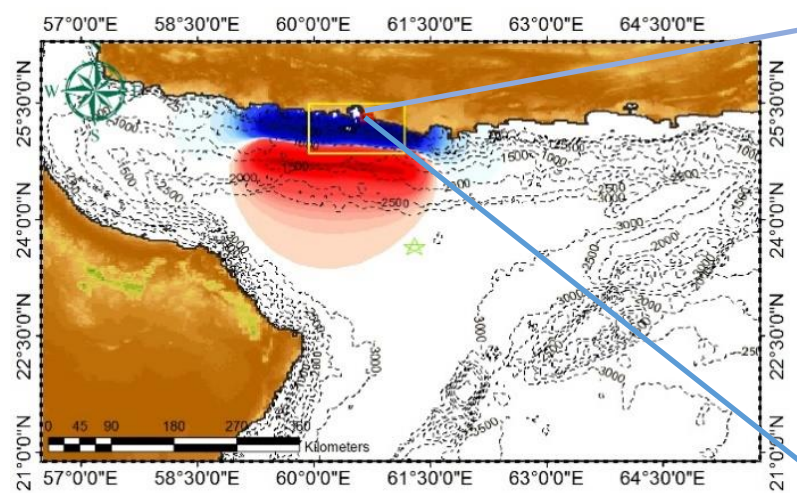

a.

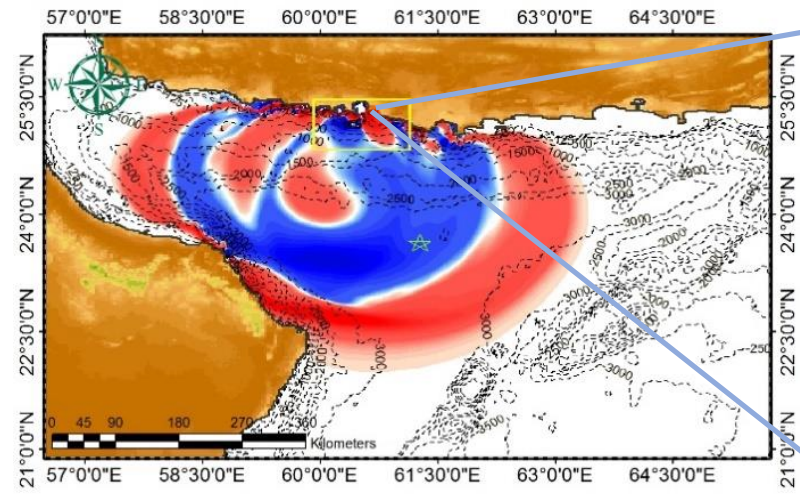

c.

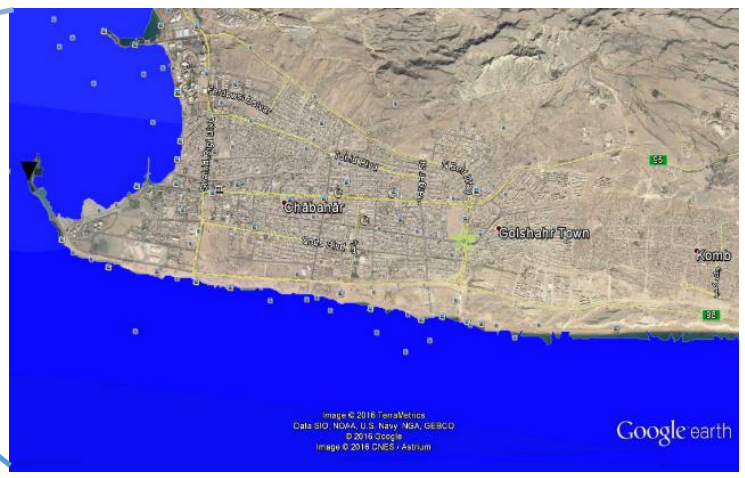

b.

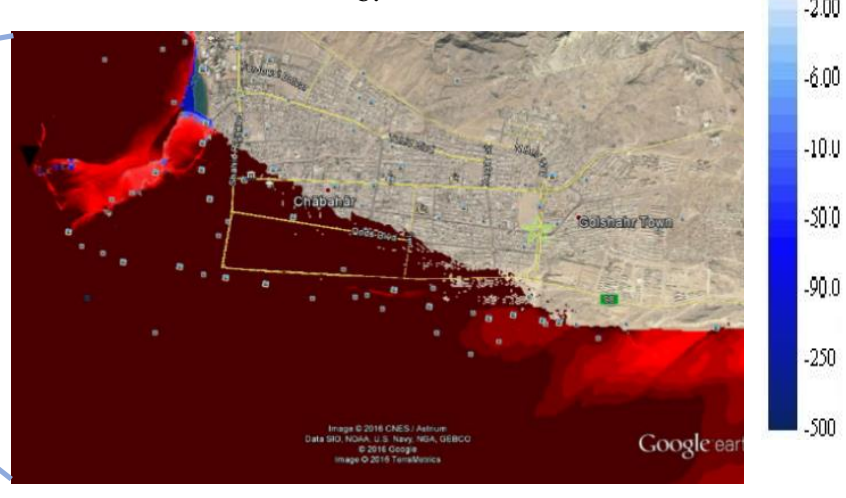

d.

Figure 8. Snapshot of sea level deformation in Makran subduction zone affected the worst case tsunami at the generation time (a), deformation of coastal level in Chabahar port at the generation time (b), propagation of the tsunami wave and deformation of the sea level at 20 minutes after tsunami generation (c), inundation tsunami on Chabahar port at 20 minutes after generation (d).

\section{CONCLUSION}

The 1945 MSZ tsunami event of Chabahar port in Iran has been modelled. The results of numerical modelling have been compared with those of the observed wave height from eyewitnesses in the Chabahar coast. The main findings of the research are summarized as follows:

1- Based on the modelling results of Makran 1945 tsunami, seafloor uplift and subsidence reaches the maximum of about $2 \mathrm{~m}(1.84 \mathrm{~m})$ which was in agreement with the actual observed uplift during the 1945 event. The maximum run-up modelling at Chabahar port was 3 meters that was also in agreement with the reports provided by the eyewitnesses.

2- Tsunami snapshot shows that 1945 event affected all neighbouring countries including Iran, Oman, Pakistan, and India. The effect of the tsunami on southern coasts of Pakistan is more than the other countries.

3- The worst case scenario snapshot shows that tsunami wave reaches to Chabahar coastline 11 minute after generation and after 20 minutes from the tsunami generation, more than $9.4 \mathrm{Km}^{2}$ of dry land will be flooded with maximum wave amplitude of 30 meters.
The accuracy of the tsunami modelling to create inundation map is directly related to the resolution of the bathymetric and topographic data used. Employing higher resolution data may lead to more accurate modelling, however, it takes much time to be processed at the modelling stage.

According to Figure 6 and 8 most of the tsunami's energy in the Makran subduction zone propagates in the north-south direction focusing on the southern coasts of Iran and Pakistan and also on the northern coast of Oman, so the Chabahar port could be affected by any tsunami in MSZ.

\section{REFERENCES}

Ambraseys, N. N., Melville, C. P., 1982. A History of Persian Earthquakes. Cambridge University Press, Cambridge, Britain, $218 \mathrm{p}$.

Byrne, D. E., Sykes, L. R., Davis, D. M., 1992. Great Thrust earthquakes and aseismic slip along the plate boundary of the Makran Subduction Zone. Journal of Geophysical Research 97 (B1), pp. 449-478.

Heidarzadeh, M., Pirooz, M. D., Zaker, N. H., Yalciner, A.C., 2008. Preliminary estimation of the tsunami hazards associated with the Makran subduction zone at the north-western Indian Ocean. Journal of Natural Hazards, Vol. 48, pp 229-243. 
Heidarzadeh, M., Pirooz, M. D., Zaker, N. H., Mokhtari, M., 2007. Numerical simulation of the 28 November 1945 Makran tsunami as a tool to assess tsunami risk in southern coasts of Iran Proc. The 5th International Conference on Seismology and Earthquake Engineering (SEE-5), Tehran, Iran, May 13-16, 2007, $8 \mathrm{p}$.

Kenji, S., Yushiro F., 2007. Tsunami Source of the 2004 Sumatra Andaman earthquake inferred from tide gauge and satellite data. International Journal of Seismological Society of America, Vol. 97. pp. 192-207.

Mansinha, L., and Smylie, D. E., 1971. The displacement field of inclined faults. Bulletin of Seismological Society of America, pp. $1433-1440$.

Murty, T. S., 1984. Storm surges - meteorological ocean tides: Canada, National Research Council of Canada. Canadian Bulletin of Fisheries and Aquatic Sciences Vol. 212, 897 p.

Okada, Y., 1985. Surface deformation due to shear and tensile faults in a half space. Bulletin of Seismological Society of America 75 (4), pp. 1135-1154.

Pacheco. J. F, Sykes. L. R., 1992. Seismic moment catalog of large shallow earthquakes, 1900 to 1989. Journal of Bulletin of the Seismological Society of America. 82, pp. 1306-1349

Page, W. D., Alt, J. N., Cluff, L. S., Plafker, G., 1979. Evidence for the recurrence of large magnitude earthquakes along the Makran coast of Iran and Pakistan. Tectonophysics 52, pp. 533547.

Satake, K., 1995. Linear and nonlinear computations of the 1992 Nicaragua earthquake tsunami. Pure and Applied Geophysics, 144, pp. 455-470.

Steketee, J. A., 1958. On Volterra's dislocations in a semiinfinite elastic medium. Canadian Journal of Physics, Vol. 36, No. 2, pp. 192-205.

Synolakis, C. E., 2003. Tsunami and Seiche, In: Earthquake Engineering Handbook. Chapter, Edited by Chen W. F., and Scawthorn, C., CRC Press.

Titov, V. V. and Synolakis, C. E., 1995. Modelling of breaking and nonbreaking long-wave evolution and run up using VTCS-2, $J$. Waterway Port Coast Ocean Eng., Vol. 121(6), pp. 308-316.

Titov, V.V. and Synolakis, C.E., 1997. Extreme inundation flow during the Hokkaido-Nansei-Oki tsunami. Geophysical Research Letters 24, pp. 1315-1318.

Titov, V. V. and Gonzalez F., 1997. Implementation and Testing of the Method of Splitting Tsunami (MOST), National Oceanic and Atmospheric Administration. Washington DC, Technical Memorandum ERL PMEL-112. 